Sains Malaysiana 50(9)(2021): 2701-2711

http://doi.org/10.17576/jsm-2021-5009-17

\title{
Ranibizumab Inhibits Human Tenon’s Fibroblast Proliferation via p21 Dependent p53 Mechanisms
}

(Ranibizumab Merencat Percambahan Fibroblas Tenon Manusia melalui Mekanisme p21 Bersandar p53)

Siti Munirah Md NoH*, Siti Hamimah Sheikh Abdul Kadir \& Sushil Vasudevan

\section{ABSTRACT}

Trabeculectomy is the gold standard procedure performed in glaucoma when topical medication and laser intervention failed. In a trabeculectomy, number of clinical trials have shown the efficacy of ranibizumab in minimizing extracellular matrix accumulation at the filtering site. Ranibizumab (Lucentis ${ }^{T M}$ ) is a drug that targets vascular endothelial growth factor (VEGF). However, to date the actual mechanisms of this anti-VEGF in trabeculectomy is still not well understood. Hence, in here we aimed to elucidate the effects of ranibizumab on human Tenon's fibroblast (HTF) isolated from patients undergoing trabeculectomy. In our previous study, we had reported that ranibizumab reduces the level of spermidine metabolite whereby spermidine is an important polyamine for cell proliferation. For this current study, cultured HTFs were divided into untreated, control IgG, ranibizumab only, difluoromethylornithine (DFMO; inhibitor of spermidine) only and ranibizumab with DFMO. All cells were extracted for PCR array (expression of CDKN1A, CDK2, and $\mathrm{CDK} 4)$ and protein expression of p53, p21, CDK2, and CDK4 by Western Blot. In here, our result demonstrated that cells treated with ranibizumab or DFMO and cells treated with ranibizumab-DFMO have similar effects as both show increased in 553 and p21. Meanwhile, no significant differences in expression of CDKN1A, CDK2 and CDK4 were observed in all groups. In essence, our findings suggest that ranibizumab action is mediated by p21 and p53.

Keywords: Human Tenon's fibroblast; ranibizumab; vascular endothelial growth factor

\section{ABSTRAK}

Trabekulektomi adalah prosedur utama yang dijalankan bagi penyakit glaukoma apabila ubatan topikal dan intervensi laser telah gagal. Dalam trabekulektomi, beberapa ujian klinikal telah menunjukkan keberkesanan ranibizumab dalam menurunkan pengumpulan metriks ekstrasel pada tapak penurasan. Ranibizumab (Lucentis ${ }^{T M}$ ) adalah sejenis dadah yang mensasarkan faktor pertumbuhan endotelium vaskular (VEGF). Namun, sehingga kini masih belum difahami sepenuhnya bagaimana anti-VEGF bekerja dalam mengurangkan kesan sampingan bagi trabekulekomi. Oleh kerana itu, kami mensasarkan untuk mengkaji kesan ranibizumab ke atas fibroblas Tenon manusia (HTF) yang telah diambil daripada pesakit yang melalui prosedur trabekulektomi. Dalam kajian lepas, kami telah melaporkan bahawa ranibizumab menurunkan kadar metabolit spermidin, iaitu sejenis poliamina penting untuk pertumbuhan sel. Dalam kajian semasa ini, kultur HTFs dibahagikan kepada tanpa rawatan, IgG kawalan, ranibizumab, difluorometilornitin (DFMO; perencat spermidin) dan ranibizumab bersama DFMO. Semua sel diekstrak untuk tatasusunan PCR (ekspresi CDKN1A, CDK2 dan CDK4) dan ekspresi protein p53, p21, CDK2 dan CDK4 secara pemblotan western. Keputusan menunjukkan sel yang dirawat ranibizumab atau DFMO serta ranibizumab dengan DFMO menyebabkan peningkatan ekspresi p53 dan p21. Sementara itu, tiada perubahan signifikan dilihat bagi CDKN1A, CDK2 dan CDK4 dalam semua sel. Secara ringkasnya, keputusan kami mencadangkan bahawa ranibizumab mungkin bertindak melalui protein p21 dan p53.

Kata kunci: Faktor pertumbuhan endotelium vaskular; fibroblas Tenon manusia; ranibizumab

\section{INTRODUCTION}

Vascular proliferation and angiogenesis are the important processes in wound healing and tissue scarring. The onset of these two processes are significantly regulated by numbers of growth factors, most conspicuously vascular endothelial growth factor A (VEGF-A)(Napoleone 2004). 
VEGF and its receptors represent one of the best validated signaling pathways in angiogenesis and its involvement in ocular diseases such as neovascularization in age-related macular degeneration (NV-AMD), diabetic retinopathy, and neovascular glaucoma has been well-documented (Akiyode \& Tran 2016; Napoleone 2004). Significant level of VEGF has also been implicated in the subconjunctival fibrosis following trabeculectomy, where it interacts with numerous cytokines and growth factors to promote ECM deposition at surgical site. Interestingly, inhibition of VEGF has been shown to effectively minimize fibrotic activities and subsequently lead to scar formation, thus increase the success of trabeculectomy (Van Bergen et al. 2014). The breakthrough of anti-vascular endothelial growth factor (anti-VEGF) agents has offers the worthwhile alternative in anti-scarring and wound healing strategy following trabeculectomy.

Ranibizumab is one of the anti-VEGF which has been authorized by US Food and Drug Administration (FDA) to be used for various ocular diseases treatment, including in the management of anti-fibrotic strategy following trabeculectomy (Elmekawey \& Khafagy 2014). Findings from numbers of clinical studies have deliberately described the potency of ranibizumab as an anti-scarring agent in trabeculectomy, however, the actual mechanisms involve is not well understood (Akiyode \& Tran 2016). Siti Munirah et al. $(2019,2014)$ reported reported that ranibizumab significantly inhibit cultured HTFs cell viability, however its effects on common proteins involve in scar formation and ECM component are not definitive.

Spermidine has been recognized as an important metabolite in cells undergoing rapid division and growth (Patocka \& Kuehn 2000). Inhibition in spermidine synthesis leads to cell growth arrest, reduce vascular smooth muscle cells migration and regulate other growth factor activity which subsequently reduces DNA synthesis (Liang et al. 2004). Spermidine and its precursor putrescine has been shown to play a central role in the regulation of cell growth and proliferation (Alhonen et al. 2000; Patocka \& Kuehn 2000). Level of spermidine is highly regulated by ornithine decarboxylase (ODC) which catalyzes the first and rate limiting step in the polyamine biosynthetic pathway through decarboxylation of amino acid ornithine to putrescine (Alexiou et al. 2015). A number of compounds have been recognized as a potent inhibitor to spermidine synthesis. Application of DFMO on mammalian cells cultures, generally results in suppression of putrescine and spermidine level in which intracellular pools depend on ODC activity. As shown in normal rat intestinal cells (IEC-6), inhibition of ODC by DFMO has significantly reduced spermidine level accompanied with an increase in p53 level at both mRNA and protein level (Alhonen et al. 2000). In this study, we aimed to evaluate the anti-fibrotic property of ranibizumab in comparison to DFMO by investigating the level regulatory genes and proteins that involve in cell cycle regulation such as p53, CDKN1A, p21, CDK2 and CDK4.

\section{MATERIALS AND METHODS}

\section{SAMPLE COLLECTION AND CELL CULTURE}

In here, Tenon's capsule was collected from patients (aged 18 to 65 ) of primary open-angle glaucoma (POAG) who were undergoing trabeculectomy. This study was granted with ethical approval from Universiti Teknologi MARA Ethics Committee Board; 600-RMI (5/1/6) and National Medical Research Register (NMRR) (Research ID:10601). Patients under topical anti-glaucomatous drugs with a history of eye related- inflammatory condition such as scleritis were excluded. All the collected Tenon's capsule was cultured in Roswell Park Memorial Institution (RPMI) culture media (Gibco; Life Technology Grand Island, NY) supplemented with fetal bovine serum (FBS), $20 \%$ of the final volume (Gibco, Life Technology, Grand Island, NY), penicillin 100,000 U/I, and streptomycin 10 mL/L (Gibco, Life Technology, Grand Island, NY) (Siti Munirah et al. 2014). The culture was maintained at 37 ${ }^{\circ} \mathrm{C}$ in $5 \% \mathrm{CO}$ in a humidified atmosphere. For this study, only HTFs from third to sixth passages were used for all experiments. These different passages of cells were used as biological replicates $(n=4)$.

\section{HUMAN TENON'S FIBROBLAST TREATMENT GROUPS}

HTFs was divided into five groups and received treatment as in Table 1. Ranibizumab was used at concentration of $0.5 \mathrm{mg} / \mathrm{mL}$ (Novartis, Switzerland) and DFMO with the concentration of $5 \mathrm{mM}$ was chosen based on report by Alexiou et al. (2015). Control IgG (Invitrogen, USA) group was included as control for ranibizumab (a fraction of $\operatorname{IgG}$ ). HTFs were seeded in six-well plates at a density of $3 \times 10^{5}$ cells/well in complete RPMI culture media supplemented with 5\% FBS and incubated for 24 $\mathrm{h}$ in humidified environment at $37{ }^{\circ} \mathrm{C}$ with $5 \% \mathrm{CO}$. Then, the culture media was replaced with serum-free media and incubated further for $24 \mathrm{~h}$ in the same environment. Subsequently, the existing media was removed and each group received their respective treatment and incubated for $48 \mathrm{~h}$. 
TABLE 1. Treatment groups for HTFs

\begin{tabular}{cl}
\hline Group & Treatment \\
\hline Group 1 & Serum-free culture media only \\
Group 2 & $0.5 \mathrm{mg} / \mathrm{mL}$ control IgG in serum-free media \\
Group 3 & $0.5 \mathrm{mg} / \mathrm{mL}$ ranibizumab in serum-free media \\
Group 4 & $5 \mathrm{mM}$ DFMO in serum-free media \\
Group 5 & $0.5 \mathrm{mg} / \mathrm{mL}$ ranibizumab and $5 \mathrm{mM}$ DFMO in serum-free media \\
\hline
\end{tabular}

\section{PCR ARRAY}

Once the incubation completed, all media in the well was removed. Briefly, HTFs were washed and lysed using RNAeasy mini extraction kit (Qiagen, USA). The lysate was then pipetted directly into the first spin column and centrifuged. Then, the lysate was homogenized and 70\% ethanol was added to the homogenized lysate. Then, the sample was transferred into the second spin column placed in a $2 \mathrm{~mL}$ collection tube and centrifuged at $8,000 \times \mathrm{g}$ for $15 \mathrm{~s}$ sets at $10{ }^{\circ} \mathrm{C}$. The flow through was discarded and the step was repeated again. Finally, the third spin column was placed in a new $15 \mathrm{~mL}$ collection tube of RNase-free water was directly added to the spin column and centrifuged at $8,000 \times \mathrm{g}$ for one minute. The elute was stored in $80^{\circ} \mathrm{C}$ until used. RNA concentration was quantified by Nanodrop1000 Spectrophotometer (Thermo Scientific, Waltham, MA, USA). Subsequently, 400 ng RNA was use to synthesized to cDNA using iScript cDNA Synthesis Kit (Bio-Rad, US).

$\mathrm{RT}^{2}$ Profiler PCR Array (Qiagen, Germany) was used to investigate mRNA expression of $C D K N 1 A, C D K 2$ and $C D K 4$. GAPDH, ACTB and HPRT1 were chosen as housekeeping genes. List of targeted and housekeeping mRNAs are shown in Table 2.

TABLE 2. Targeted and housekeeping mRNAs

\begin{tabular}{lll}
\hline \multicolumn{1}{c}{ Description } & Genbank & Symbol \\
\hline Cyclin-dependent kinase inhibitor 1A(p21,Cip1) & NM_000389 & CDKN1A \\
Cyclin-dependent kinase 2 & NM_001798 & CDK2 \\
Cyclin-dependent kinase 4 & NM_000075 & CDK4 \\
Glyrealdehyde-3-phosphate dehydrogenase & NM_002046 & GAPDH \\
Actin, Beta & NM_001101 & ACTB \\
Hypoxanthine phosphoribosyltransferase 1 & NM_000194 & HPRT \\
\hline
\end{tabular}




\section{WESTERN BLOT ASSAY}

Once the $48 \mathrm{~h}$ incubation completed, all media in the well was removed. HTFs layer was washed with $1 \mathrm{~mL}$ of phosphate buffer saline (PBS). Subsequently, $300 \mu \mathrm{L}$ of RIPA lysis buffer was added into the well, and HTFs was scrapped off with cell scrapper. The lysate was then transferred into $2 \mathrm{~mL}$ micro-centrifuge tube and sonicated with RICO Sonicator Bath (Rico Scientific, New Delhi, India) at $40 \mathrm{~V}$ for $20 \mathrm{~min}$. The lysate then was centrifuged at $11,000 \times \mathrm{g}$ for $15 \mathrm{~min}$ at $4{ }^{\circ} \mathrm{C}$ with Eppendorf Centrifuge 5424 (Eppendorf, Hauppauge, NY, USA). The supernatant was transferred into new microcentrifuge tube. The protein extracted was quantified by NanoDrop 1000 Spectrophotometer (Thermo Scientific, Waltham, MA, USA). Sample and control protein were standardized to $25 \mu \mathrm{g}$ per $30 \mu \mathrm{L}$ of samples in microcentrifuge tubes. The Western Blot assay comprised of two parts; the SDSPAGE of protein sample follows by the immunoblotting or protein blotting. All samples were subjected to the dilution with Laemli buffer at 1:1 ratio. Approximately, $10 \mu \mathrm{L}$ of samples and controls were mixed with $10 \mu \mathrm{L}$ of Laemli buffer in microcentrifuge tube. The lysates were then incubated at $950{ }^{\circ} \mathrm{C}$ for $5 \mathrm{~min}$ in T 100 Thermal Cycler (Bio-Rad, Hercules, CA, USA).

Sodium Dodecyl Sulfate (SDS) gel is a separating gel topped by stacking gel prepared above the resolving gel which seconded in electrophoresis apparatus. Firstly, the resolving gel was prepared by mixing $4 \mathrm{~mL}$ of resolving buffer (pH:8.8) with $6.68 \mathrm{~mL}$ of $30 \%$ Acrylamide/Bis (Bio-Rad, Hercules, CA, USA), $4.98 \mathrm{~mL}$ of ddH2O, 200 $\mu \mathrm{L}$ of $10 \%$ SDS (Bio-Rad, Hercules, CA, USA), $200 \mu \mathrm{L}$ of $10 \%$ of APS (Bio-Rad, Hercules, CA, USA) and 40 $\mu \mathrm{L}$ of TEMED (Himedia, Mumbai, India). The mixture was mixed thoroughly and immediately poured into the casting stand. The gel was left to polymerize for $30 \mathrm{~min}$. Then, stacking gel was prepared by mixing of $2.5 \mathrm{~mL}$ of stacking buffer (pH: 6.8) with $1.3 \mathrm{~mL}$ of $30 \%$ Acrylamide/ Bis, $6.05 \mathrm{~mL}$ of ddH2O, $100 \mu \mathrm{L}$ of $10 \%$ SDS, $100 \mu \mathrm{L}$ of APS and $10 \mu \mathrm{L}$ of TEMED. The mixture then immediately poured onto the resolving gel layer. Subsequently, the gel comb was gently inserted into the stacking gel.

Prior to Sodium Dodecyl Sulfate-Polyacrylamide Gel Electrophoresis (SDS-PAGE) run, the electrophoresis tank was filled with running buffer until it was half full. Running buffer was also filled into the empty space between the two glass plates (dam) until full and any leakage was checked. Once marker and samples were loaded, the $90 \mathrm{~V}$ current was run across the gel for $120 \mathrm{~min}$. Upon completion electrophoresis, the SDS-PAGE gel was carefully removed from the glass plate and assembled in the blotting system in systematic order to ensure complete protein transfer. Semi-dry electrophoretic transfer method has been used to transfer the protein into the nitrocellulose membrane. Protein was transferred into nitrocellulose membrane for 30 min using semi-dry electrophoretic transfer method with Trans-Blot Turbo Blotting System (Bio Rad, Hercules, CA, USA). Subsequently, the membrane was stained with Ponceau S (Advansta, San Jose, CA, USA) to observe the band for complete transfer process. For band visualization, the blotted membrane was blocked immediately with 5\% Bovine Serum Albumin (BSA) (Sigma Aldrich, St. Louis, Missouri, USA) for $2 \mathrm{~h}$ and then incubated with diluted monoclonal primary antibody p53 (Cell Signalling Technology, Danver, MA, USA) (1:500), p21 (Cell Signalling Technology, Danver, MA, USA) (1:500), CDK2 (Cell Signalling Technology, Danver, MA, USA) (1:500) and CDK4 (Cell Signalling Technology, Danver, MA, USA) (1:500) for overnight at $4{ }^{\circ} \mathrm{C}$ on rotary shaker. After removal of the primary antibody, the blot was incubated with horseradish peroxide-conjugated goat anti-rabbit (1:2000) for $2 \mathrm{~h}$ prior to detection. Immunoreactions were detected using Western Bright Quantum HRP substrate (Advansta, San Jose, CA, USA) and developed using CLExposure film (Thermo Scientific, Life Technologies, San Diego, CA, USA) for $15 \mathrm{~s}, 30 \mathrm{~s}$ and $40 \mathrm{~s}$.

\section{STATISTICAL ANALYSIS}

Data were presented as means \pm standard deviation (SD). Four biological replicates and three technical replicates were employed for each experiment. Statistical evaluation of significant differences was performed using the KruskalWallis test for mean comparison and Mann-Whitney U test for multiple comparisons. P values less than 0.05 were considered statistically significant. The statistical analysis was performed with IBM SPSS Version 25.

\section{RESUlTS AND DISCUSSION}

The role of VEGF has been extensively studied as a potent regulator in normal and abnormal angiogenesis (Napoleone 2010; Nissen et al. 1998). Beside VEGF, natural polyamine such as spermidine has also been shown to have a basic role in the regulation of cells growth and differentiation. Moreover, down-regulation of cellular spermidine was associated with inhibition of growth and programmed cell death (Alhonen et al. 2000). 
Spermidine levels is highly regulated by DFMO, where it affects spermidine biosynthesis by inhibiting ODC activity (Li et al. 1999; Patocka \& Kuehn 2000). Meanwhile, deactivation of VEGF by anti-VEGF has markedly inhibits cell proliferation and angiogenesis (Herbst et al. 2005). Due to these facts, in here we compared the effects of ranibizumab and DFMO in the HTFs.

Cell cycle progression has been demonstrated to be regulated by a class of regulators called cyclin dependent kinase (CDK) inhibitor. The first protein identified from this class was p21, which is the product of CDKN1A gene (Abukhdeir \& Park 2008). p21 plays crucial role in DNA damage response by regulating cell cycle progression, induces apoptosis and transcription process (Abukhdeir $\&$ Park 2008). Figure 1 shows expression of CDKN1A in untreated group, control IgG-treated group, ranibizumabtreated group, DFMO-treated group and ranibizumab + DFMO-treated group. As expected, no significant differences were observed in control IgG group when compared to untreated group. While in ranibizumabtreated group $(1.706 \pm 0.13 ; \mathrm{p} \leq 0.05)$, significant increase in CDKN1A expressions in comparison to untreated group were observed. The significant increase in CDKN1A expression were also observed in DFMO-treated group $(1.757 \pm 0.19 ; \mathrm{p} \leq 0.05)$ and ranibizumab + DFMOtreated group $(1.631 \pm 0.17 ; \mathrm{p} \leq 0.05)$. Additionally, no significant change in CDKN1A expression was observed in ranibizumab-treated group when compared to ranibizumab + DFMO or DFMO-treated group.

The central property of $\mathrm{p} 21$ in cell cycle arrest at G1 phase lies on its ability to inhibit the cyclin E and cyclin A, where both kinases are required for progression of G1 to S phase (Brugarolas et al. 1999). Therefore, in here we determined the expression of CDK2 and CDK4 at gene and protein level. Figure 2(A) shows expression of CDK2 in untreated group, control IgGtreated group, ranibizumab-treated group, DFMO-treated group and ranibizumab + DFMO-treated group. Control IgG-treated group demonstrated no changes in CDK2 level when compared to untreated group $(1.014 \pm 0.18$; $\mathrm{p}=0.25)$. Meanwhile, reductions in CDK2 expression were observed in ranibizumab-treated group $(0.806 \pm$ $0.12 ; \mathrm{p}=0.22)$, DFMO-treated group $(0.848 \pm 0.11 ; \mathrm{p}=$ $0.27)$ and ranibizumab + DFMO-treated group $(0.8115$ $\pm 0.13 ; \mathrm{p}=0.63)$. However, these changes were not significant when compared to control IgG or untreated group. No significant change in CDK2 expression was observed in ranibizumab-treated group when compared to ranibizumab + DFMO or DFMO-treated group. Figure 2(B) shows expression of CDK4 in untreated group, control IgG-treated group, ranibizumab-treated group, DFMOtreated group and ranibizumab + DFMO-treated group. No significant differences in CDK4 expression were observed in control IgG-treated group $(0.938 \pm 0.15 ; \mathrm{p}=0.20)$, ranibizumab-treated group $(0.869 \pm 0.17 ; \mathrm{p}=0.22)$, DFMOtreated group $(0.757 \pm 0.13 ; \mathrm{p}=0.20)$ and ranibizumab + DFMO-treated group $(0.743 \pm 0.14 ; \mathrm{p}=0.21)$.

Figure 3 shows protein expression of CDK2 in untreated group, control IgG-treated group, ranibizumabtreated group, DFMO-treated group and ranibizumab + DFMO-treated group. No significant differences were observed between all groups; ranibizumab-treated group $(0.225 \pm 0.12 ; \mathrm{p}=0.69)$, DFMO-treated group $(0.194 \pm$ $0.16 ; \mathrm{p}=0.2)$ and ranibizumab + DFMO-treated group $(0.185 \pm 0.12 ; p=0.10)$. Figure 4 shows CDK 4 protein expression in untreated group, control IgG-treated group, ranibizumab-treated group, DFMO-treated group and ranibizumab + DFMO-treated group. CDK4 protein expression was reduced in control IgG-treated group $(0.555 \pm 0.15 ; \mathrm{p}=0.20)$, ranibizumab-treated group $(0.497$ $\pm 0.17 ; \mathrm{p}=0.20)$, DFMO-treated group $(0.480 \pm 0.12 ; \mathrm{p}$ $=0.40)$ and ranibizumab + DFMO-treated group $(0.511 \pm$ $0.19 ; \mathrm{p}=0.21)$. Nevertheless, all these changes were not significant when compared to control.

Activation of p53 resulted from damaged DNA will lead to detention in DNA replication. Subsequently, this step will provide sufficient time for the cell to repair the lesion in $\mathrm{G} 1$ phase before entering $\mathrm{S}$ phase of mitosis in G2 phase. If the damage repairable, cell cycle will continue by entering the active $\mathrm{S}$ phase, or if the damage in unrepairable, the cell will undergo apoptosis (Agarwal et al. 1995). Figure 5 shows protein expression of p53 in untreated group, control IgG-treated group, ranibizumabtreated group, DFMO-treated group and ranibizumab + DFMO-treated group. No significant differences were observed in p53 expression of control IgG group when compared to untreated group. However, p53 protein expression were significantly increased in ranibizumabtreated group $(1.010 \pm 0.27 ; \mathrm{p}=0.001)$, DFMO-treated group $(0.866 \pm 0.20 ; p=0.001)$ and ranibizumab + DFMOtreated group $(0.793 \pm 0.16 ; \mathrm{p}=0.001)$ when compared to untreated group No significant changes in $\mathrm{p} 53$ protein expression level were observed in ranibizumab-treated group when compared to ranibizumab + DFMO-treated group. 
Figure 6 shows protein expression of $\mathrm{p} 21$ in untreated group, control IgG-treated group, ranibizumab-treated group, DFMO-treated group and ranibizumab + DFMOtreated group. No significant differences were observed in control IgG group when compared to untreated group. However, in ranibizumab-treated group $(0.626 \pm 0.23$; $\mathrm{p}=0.04)$, p21 protein expression was significantly increased when compared to untreated group. Similarly, significant up-regulation in p21 level were also observed in DFMO-treated group $(0.459 \pm 0.17 ; \mathrm{p}=0.01)$ and in ranibizumab + DFMO-treated group $(0.464 \pm 0.17 ; \mathrm{p}=$ $0.01)$. No significant change in p21 expression level was observed in ranibizumab-treated group when compared to ranibizumab + DFMO-treated group. As shown in this study, both ranibizumab and DFMO treatment increased p53 and p21 expression. p53 is one of the most extensively studied protein in anti-angiogenic research due to it proliferation suppressive activity and role in apoptosis and angiogenesis inhibition ( $\mathrm{Li}$ et al. 1999).

Numbers of studied have reported the association between p53 and p21 in regulating cell growth and proliferation. As indicated in this study, both ranibizumab and DFMO treatment lead to increase p53 and p21 expression. As described by Huang et al.
(2005) DFMO, induced cell cycles arrest through p53 and p21 augmentation. Disturbance in normal cell cycle regulation has led to depletion in polyamine synthesis, specifically spermidine. Therefore, we speculated that ranibizumab could be modulating HTFs cell cycle via the same manner, which is p21 dependent p53 mechanism. Interestingly in here, both ranibizumab and DFMO had also reduced the expression of CDK2 and CDK4 in cultured HTF. The insignificant reduction observed at mRNA and protein level for both CDKs could be due to the time point where the analysis was performed. As reported by Liang et al. (2004) significant reduction of CDK2 and CDK4 level has been demonstrated to occur at $24 \mathrm{~h}$ following (-)-Epigallocatechin-3-gallate (EGCG) treatment on breast cancer cell (MCF-7). In contrary to that, in this study, HTFs was exposed to ranibizumab and DFMO for $48 \mathrm{~h}$. Most probably, if the changes detection were made at the similar time point as highlighted in the said study, significant changes might be observed. Therefore, it could be postulated that both ranibizumab and DFMO induces significant elevation of $\mathrm{p} 21$ which subsequently leads to inhibition of CDK2 and CDK4. This is in line with Dulić et al. (1994) that correlates the induction in expression of p53 and p21 protein to the down-regulation of CDK2 and CDK4.

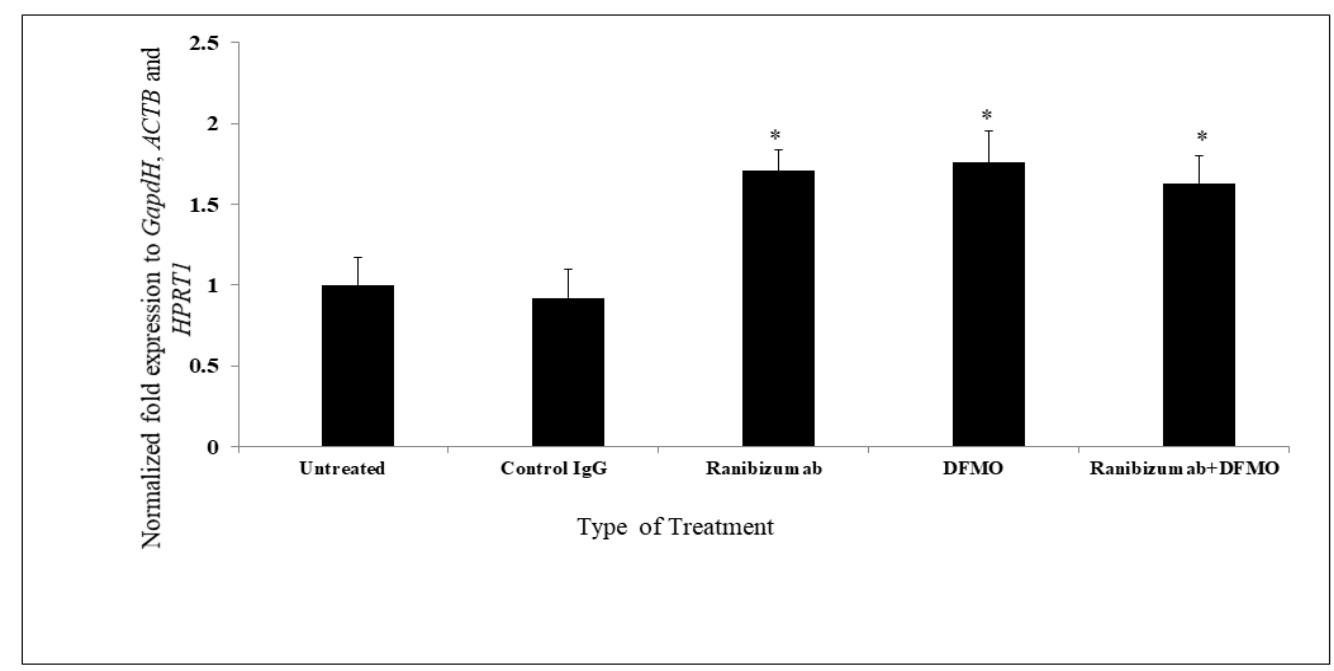

FIGURE 1. Effect of ranibizumab treatment on CDKN1A expression in cultured HTFs. Ranibizumab-treated group, DFMO-treated group and ranibizumab + DFMO-treated group demonstrated significant increase in $C D K N 1 A$ expression level when compared to untreated group. CDKN1A level was reduced in control IgG-treated group; however, the reduction was not significant when compared to untreated group

(*comparison to control; $(\mathrm{p}<0.05) ; \mathrm{n}=4$ independent experiments) 
A

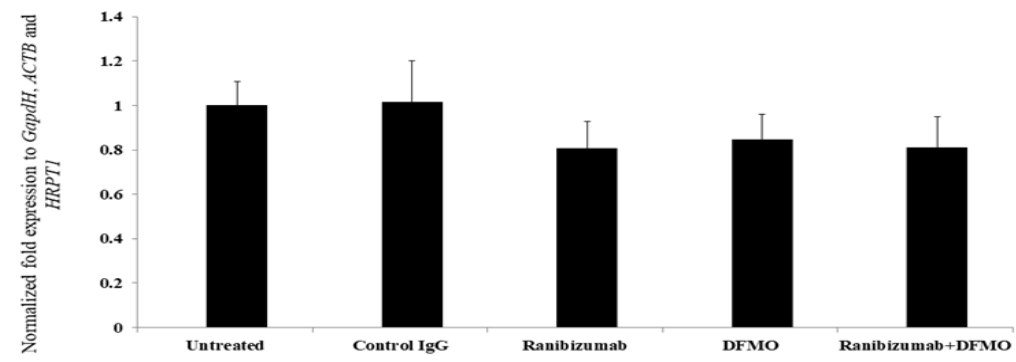

B

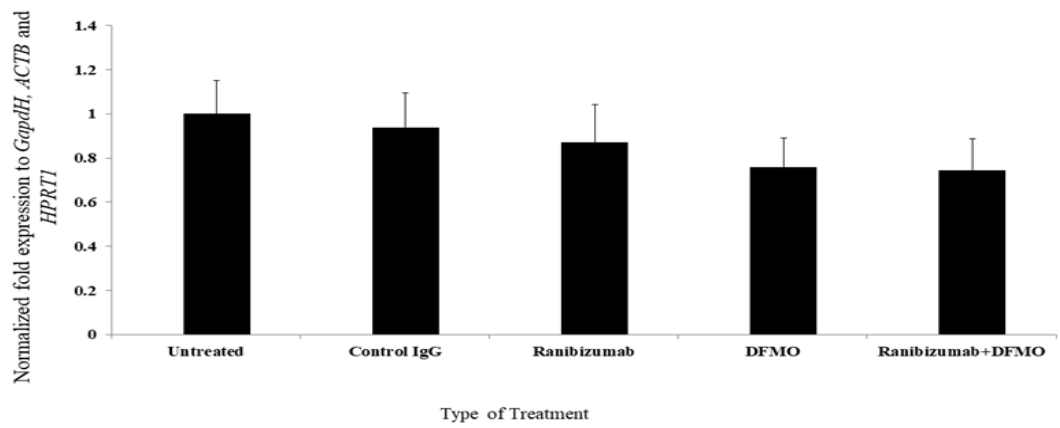

FIGURE 2. Effect of ranibizumab treatment on $C D K 2$ (A) and $C D K 4$ (B) expression in cultured HTF. $C D K 2$ and $C D K 4$ expression were reduced in ranibizumab-treated group, DFMO-treated group and ranibizumab + DFMO-treated group, however these changes were not significant when compared to untreated group

*comparison to control; $(\mathrm{p}<0.05) ; \mathrm{n}=4$ independent experiments
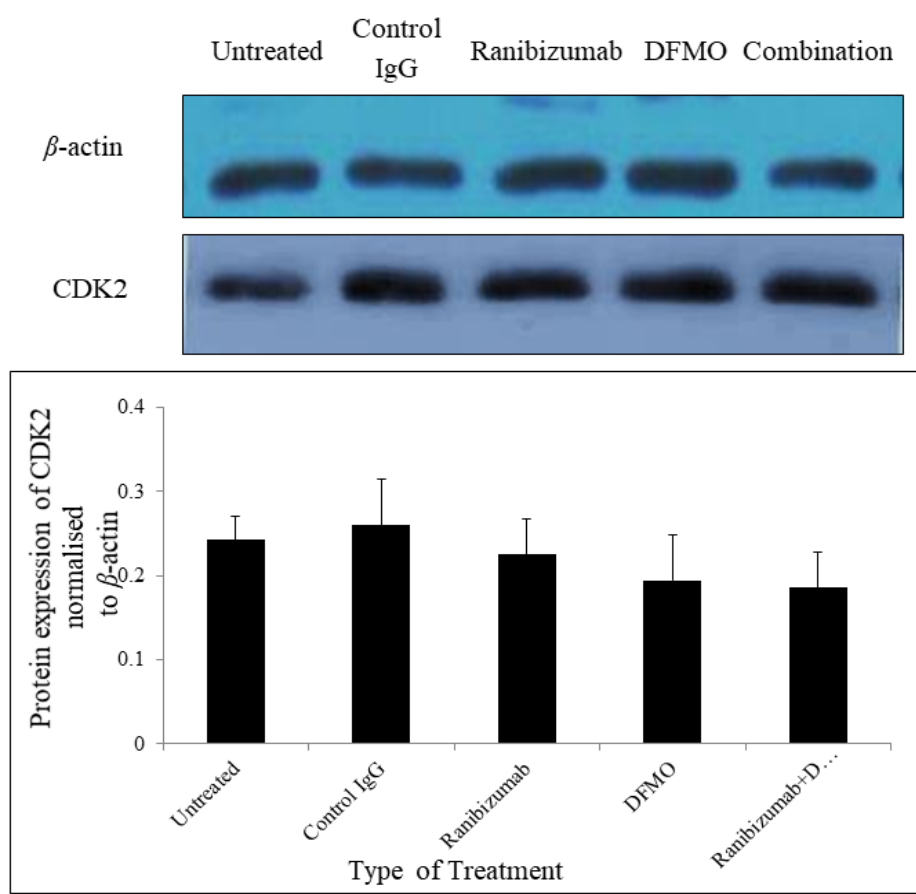

FIGURE 3. Effect of ranibizumab treatment on $C D K 2$ protein expression in cultured HTF. Protein expressions of $C D K 2$ protein were unchanged in control IgG-treated group. $C D K 2$ protein expressions were down-regulated in ranibizumab-treated group, DFMO-treated group and ranibizumab + DFMO-treated group. However, these changes were not significant when compared to untreated group 

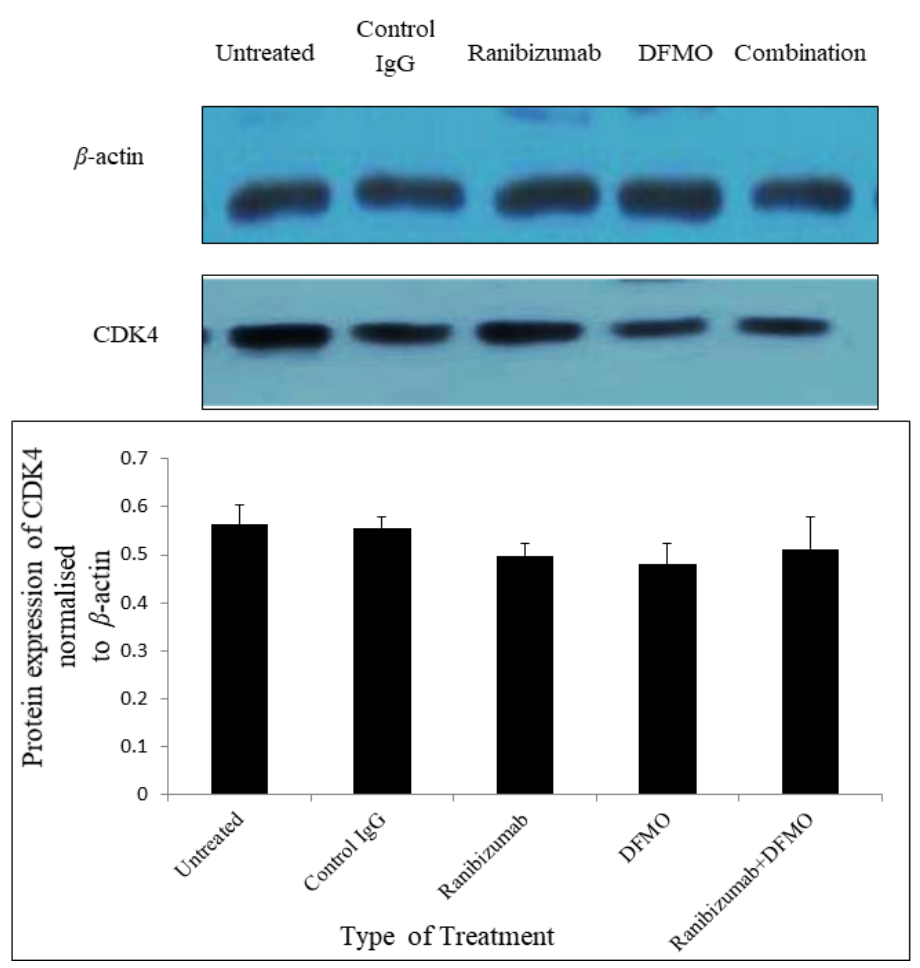

FIGURE 4. Effect of ranibizumab treatment on $C D K 4$ protein expression in cultured HTF. CDK4 protein expression was reduced in control IgG-treated group, ranibizumab-treated, DFMO-treated and ranibizumab + DFMO-treated group. These changes were not significant when compared to control

*comparison to control; $(\mathrm{p}<0.05) ; \mathrm{n}=4$ independent experiments

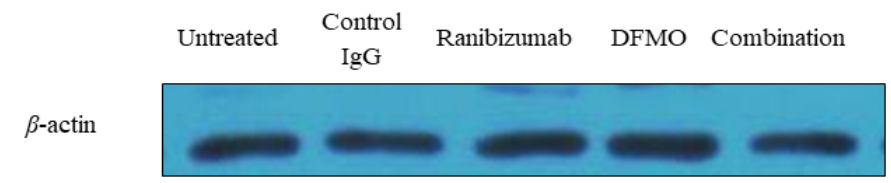

$\mathrm{p} 53$
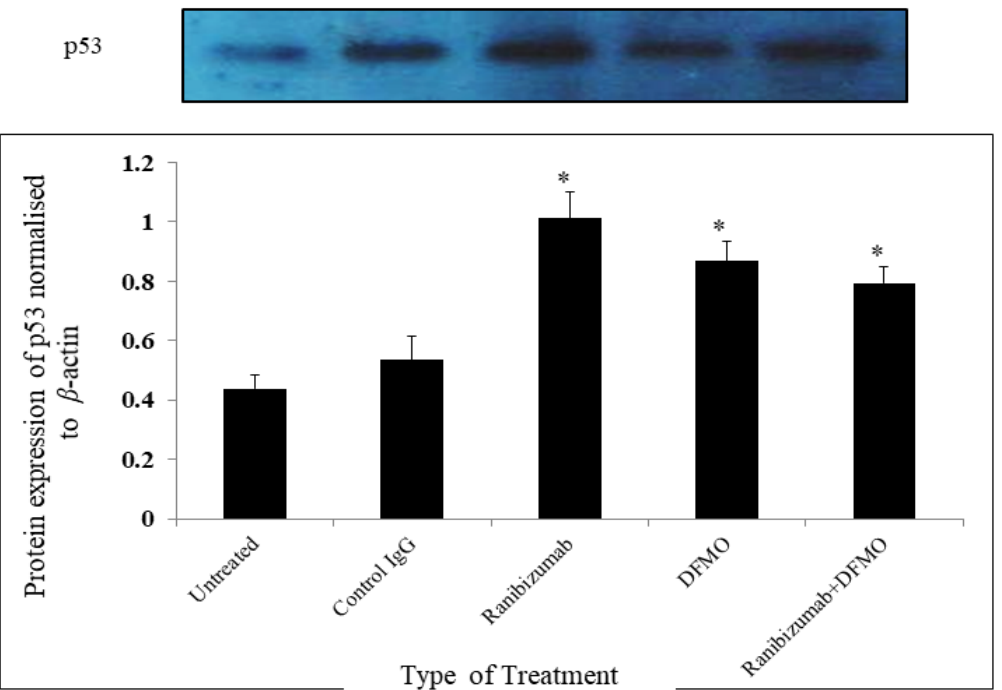

FIGURE 5. Effect of ranibizumab treatment on $\mathrm{p} 53$ protein expression in cultured HTF. Ranibizumab-treated group, DFMO-treated group and ranibizumab + DFMOtreated group demonstrated significant increase in protein expressions of $\mathrm{p} 53$ when compared control IgG group. No significant change in control IgG-treated group was observed when compared to untreated group 


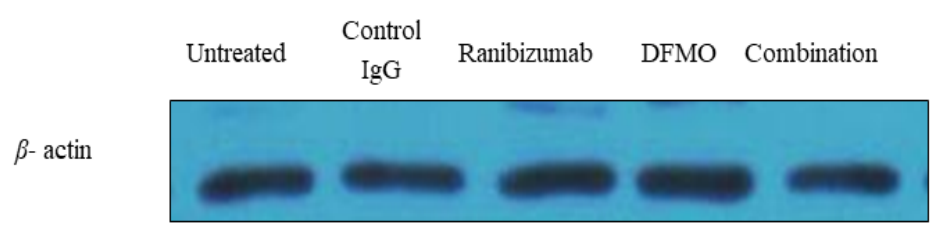

p 21
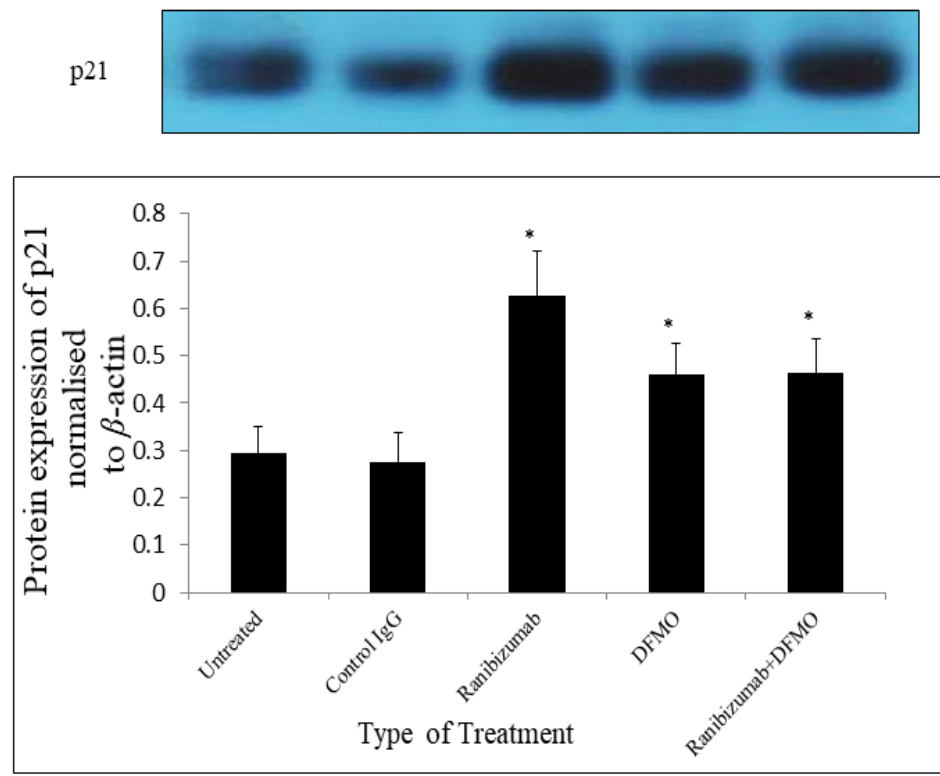

FIGURE 6. Effect of ranibizumab treatment on $\mathrm{p} 21$ protein expression in cultured HTF. Ranibizumab-treated group, DFMO-treated group and ranibizumab + DFMOtreated group demonstrated significant increase in protein expressions of $\mathrm{p} 21 \mathrm{when}$ compared to untreated group. No significant change in control IgG-treated group was observed when compared to untreated group

*comparison to control; $(\mathrm{p}<0.05) ; \mathrm{n}=4$ independent experiments

\section{CONCLUSION}

This study suggested that anti-scarring mechanism of ranibizumab is exerted through p21 dependent p53 mechanisms. We postulated that ranibizumab decreases ECM accumulation at the filtering bleb is mediated by the expression of p53 and p21. High level of p21 decreases the expression of $C D K 2$ and $C D K 4$ which eventually result in cell cycle arrest. Overall, these findings suggest ranibizumab as a potent modulator in scarring process following trabeculectomy.

\section{ACKNOWLEDGEMENTS}

This research was funded by the Ministry of Science, Technology and Innovation (MOSTI), Malaysia. Project Code: 100-RMI/SF 16/6/2 and Ministry of Higher Education, Malaysia: FRGS Project code: 600-RMI.FRGS $5 / 3(33 / 2013)$.

\section{REFERENCES}

Abukhdeir, A.M. \& Park, B.H. 2008. p21 and p27: Roles in carcinogenesis and drug resistance. Expert Reviews in Molecular Medicine 10: e19. https://doi.org/10.1017/ S1462399408000744. 
Agarwal, M.L., Agarwal, A., Taylor, W.R. \& Stark, G.R. 1995. P53 controls both the G2/M and the G1 cell cycle checkpoints and mediates reversible growth arrest in human fibroblasts. Proceedings of the National Academy of Sciences of the United States of America 92(18): 8493-8497. https://doi. org/10.1073/pnas.92.18.8493.

Akiyode, O. \& Tran, C. 2016. Overview of ocular anti-vascular endothelial growth factor therapy in the management of diabetic eye complications. Diabetes Spectrum 29(1): 44-49. https://doi.org/10.2337/diaspect.29.1.44.

Alexiou, G.A., Tsamis, K.I., Vartholomatos, E., Peponi, E., Tzima, E., Tasiou, I., Lykoudis, E., Tsekeris, P. \& Kyritsis, A.P. 2015. Combination treatment of TRAIL, DFMO and radiation for malignant glioma cells. Journal of NeuroOncology 123(2): 217-224. https://doi.org/10.1007/s11060015-1799-9.

Alhonen, L., Parkkinen, J.J., Keinänen, T., Sinervirta, R., Herzig, K.H. \& Jänne, J. 2000. Activation of polyamine catabolism in transgenic rats induces acute pancreatitis. Proceedings of the National Academy of Sciences of the United States of America 97(15): 8290-8295. https://doi. org/10.1073/pnas.140122097.

Brugarolas, J., Moberg, K., Boyd, S.D., Taya, Y., Jacks, T. \& Lees, J.A. 1999. Inhibition of cyclin-dependent kinase 2 by P21 is necessary for retinoblastoma protein-mediated G1 arrest after $\gamma$-irradiation. Proceedings of the National Academy of Sciences of the United States of America 96(3): 1002-1007. https://doi.org/10.1073/pnas.96.3.1002.

Dulić, V., Kaufmann, W.K., Wilson, S.J., Tisty, T.D., Lees, E., Harper, J.W., Elledge, S.J. \& Reed, S.I. 1994. P53dependent inhibition of cyclin-dependent kinase activities in human fibroblasts during radiation-induced G1 arrest. Cell 76(6): 1013-1023. https://doi.org/10.1016/00928674(94)90379-4.

Elmekawey, H. \& Khafagy, A. 2014. Intracameral ranibizumab and subsequent mitomycin $\mathrm{C}$ augmented trabeculectomy in neovascular glaucoma. Journal of Glaucoma 23(7): 437-440. https://doi.org/10.1097/IJG.0b013e3182946398.

Herbst, R.S., Johnson, D.H., Mininberg, E., Carbone, D.P., Henderson, T., Kim, E.S., Blumenschein Jr., G., Lee, J.J., Liu, D.D., Truong, M.T., Hong, W.K., Tran, H., Tsao, A., Xie, D., Ramies, D.A., Mass, R., Seshagiri, S., Eberhard, D.A., Kelley, S.K. \& Sandler, A. 2005. Phase I/II trial evaluating the anti-vascular endothelial growth factor monoclonal antibody bevacizumab in combination with the HER-1/epidermal growth factor receptor tyrosine kinase inhibitor erlotinib for patients with recurrent non-small-cell lung cancer. Journal of Clinical Oncology 23(11): 2544-2555.

Huang, Y., Pledgie, A., Rubin, E., Marton, L.J., Woster, P.M., Saraswati Sukumar, Casero, R.A. \& Davidson, N.E. 2005. Role of P53/P21Waf1/Cip1 in the regulation of polyamine analogue-induced growth inhibition and cell death in human breast cancer cells. Cancer Biology and Therapy 4(9): 10061013. https://doi.org/10.4161/cbt.4.9.1970.

Liang, M., Ekblad, E., Hellstrand, P. \& Nilsson, B.O. 2004. Polyamine synthesis inhibition attenuates vascular smooth muscle cell migration. Journal of Vascular Research 41(2): 141-147. https://doi.org/10.1159/000077133.

Li, L., Li, J., Rao, J.N., Li, M., Bass, B.L. \& Wang, J.Y. 1999. Inhibition of polyamine synthesis induces P53 gene expression but not apoptosis. American Journal of Physiology - Cell Physiology 276(4): C946-C954. https:// doi.org/10.1152/ajpcell.1999.276.4.c946.

Napoleone, F. 2010. Pathways mediating VEGF-independent tumor angiogenesis. Cytokine and Growth Factor Reviews 21(1): 21-26. https://doi.org/10.1016/j.cytogfr.2009.11.003.

Napoleone, F. 2004. Vascular endothelial growth factor: Basic science and clinical progress. Endocrine Reviews 25(4): 581-611. https://doi.org/10.1210/er.2003-0027.

Nissen, N.N., Polverini, P.J., Koch, A.E., Volin, M.V., Gamelli, R.L. \& DiPietro, L.A. 1998. Vascular endothelial growth factor mediates angiogenic activity during the proliferative phase of wound healing. American Journal of Pathology 152(6): 1445-1452.

Patocka, J. \& Kuehn, G.D. 2000. Natural polyamines and their biological consequence in mammals. Acta Medica (Hradec Králové)/Universitas Carolina, Facultas Medica Hradec Králové 43(4): 119-124. https://doi. org/10.14712/18059694.2019.124.

Siti Munirah Md. Noh, Siti Hamimah Sheikh Abdul Kadir \& Sushil Vasudevan. 2019. Important metabolites in maintaining folate cycle, homocysteine, and polyamine metabolism associated with ranibizumab treatment in cultured human Tenon's fibroblasts. Biomolecules 9(6): 1-12. https://doi.org/10.3390/biom9060243.

Siti Munirah Md Noh, Siti H. Sheikh Abdul Kadir, Zakaria M. Bannur, Gabriele Anisah Froemming, Narimah Abdul Hamid Hasani, Hapizah Mohd Nawawi, Jonathan G. Crowston \& Sushil Vasudevan. 2014. Effects of ranibizumab on the extracellular matrix production by human tenon's fibroblast. Experimental Eye Research 127: 236-242. https:// doi.org/10.1016/j.exer.2014.08.005.

Van Bergen, T., Van de Velde, S., Vandewalle, E., Moons, L. \& Stalmans, I. 2014. Improving patient outcomes following glaucoma surgery: State of the art and future perspectives. Clinical Ophthalmology 8: 857-867. https://doi.org/10.2147/ OPTH.S48745.

Siti Munirah Md Noh*

University of Malaya Centre of Innovation

and Commercialization (UMCIC)

University of Malaya

50603 Kuala Lumpur, Federal Territory

Malaysia 
Siti Hamimah Sheikh Abdul Kadir \& Sushil Vasudevan Faculty of Medicine

Universiti Teknologi MARA

Cawangan Sungai Buloh

47000 Sungai Buloh, Selangor Darul Ehsan

Malaysia

Siti Hamimah Sheikh Abdul Kadir

Institute for Pathology

Laboratory and Forensic Medicine (I-PPerForM)

Universiti Teknologi MARA

Cawangan Sungai Buloh

47000 Sungai Buloh, Selangor Darul Ehsan

Malaysia
*Corresponding author; email: sitimunirah.umcic@um.edu.my

Received: 11 August 2020

Accepted: 19 January 2021 